\title{
Notes and Comment
}

\section{On eye-position hysteresis effects of backward head tilt}

\author{
SHELDON M. EBENHOLTZ \\ University of Wisconsin \\ Madison, Wisconsin 53706
}

A recent formulation of the mechanisms underlying the initiation and modulation of eye-muscle aftereffects is of use in accounting for one such aftereffect recently discovered by Shebilske and Fogelgren (1977), which in the absence of this context appears rather puzzling. Their study was based upon the fact that with backward body tilt there occurs a reflexive ocular counterrolling in the downward direction (Schubert \& Brecher, 1935). The magnitude of this "doll reflex" (DR) was shown by Ebenholtz and Shebilske (1975) to be described fairly well as a sine function of the angle of tilt of the utricular maculae, the latter being a major control center for the DR (Szentagothai, 1964). Since the nervous output of the utricles is dependent upon the shear component of gravito-inertial force acting on the hairs of the utricular maculae (Trincker, 1962), utricular innervation also is a sine function of degree of tilt of the macular surface. Thus, the DR is a relatively direct indicator of the level of activation of its control center in the utricles, and the output from this center may be modulated simply by tilting the head.

Reflexive innervation is not registered at conscious levels of the nervous system and, as a consequence, an elevation illusion occurs in which objects at fixed orientation in relation to the observer appear to increase in height with backward body tilt (Cohen, 1973; Ebenholtz \& Shebilske, 1973). The illusion may be inferred from the premise that, in order to fixate a target, voluntary innervation will be required to counteract the downward pull on the eye due to the DR. Assuming voluntary innvervation to be registered at conscious levels, and since the magnitude of the reflexive innervation will increase from the upright through about $60^{\circ}$ of head and body tilt, the target will appear to rise in this range as well.

Shebilske and Fogelgren (1977) reasoned that sustained exposure to the DR and the associated elevation illusion should give rise to a negative aftereffect, analogous to the negative aftereffects of viewing through a base-down prism. During three 3-min exposure periods, their subjects read passages while the head was tipped back $20^{\circ}$, with the reading material carefully stationed to keep the eyes at their normal straight-ahead position in relation to the head.
Before and again after each exposure period, the eye position representing the subjective straight ahead was measured with the head upright. In addition, a control group was treated identically, except that the reading period occurred with the head upright. The results were conclusive in revealing an experimentalcontrol difference in pre- to posttest shifts averaging about $3.5^{\circ}$ after the total 9-min exposure period. The direction of the effect was such that a visual target that appeared to be straight ahead actually was elevated relative to the preexposure setting. Since a target that was truly stationed at the preexposure straight-ahead position would, by inference, appear too low, the obtained effect may be described as a negative aftereffect, i.e., negative in relation to the apparent upward shift during the exposure period.

There is one puzzling aspect of this outcome. With backward head tilt, the DR caused the innervation, probably of the inferior rectus and superior oblique. Consequently, in order to maintain fixation and saccadic control during reading, other oculomotor centers had to compensate by innervating the antagonist pairs, the superior rectus and inferior oblique, respectively. We have here a case of dynamic equilibrium of sorts where, according to the inertial rule, which appears to govern eye-muscle aftereffects, one should expect to find, with head set upright, residual muscle tonus in both the downward- and upwardacting sets of muscles, with the consequence that two aftereffects of opposing direction should result. One possible inference to be drawn from this analysis, in light of the actual result, is that the obtained effect was itself a net effect, viz, the algebraic sum of the aftereffects of opposed direction, showing the upward-acting muscle pairs to be substantially more effective. But, since the degree of innervation of these muscles was exactly enough to balance the downwardacting DR, and, assuming approximate equivalence of muscle size, since the magnitude of the aftereffect is roughly proportional to the level of innervation (Matthaei, 1924), the two postulated aftereffects should have cancelled each other. The possibility of a net effect of zero, however, cannot be correct. Furthermore, it appears that the obtained aftereffect reflects the action primarily of the compensatory innervation of the upward-acting muscle set and that the DR yields only a small aftereffect of its own, if any. Fortunately, the latter is logically consistent with a recent analysis (Ebenholtz, in press) of the conditions necessary for the erasure of muscle aftereffects.

The analysis was based upon the premise that eye- 
muscle aftereffects reflect hysteresis effects in the oculomotor centers in that some portion of the innervation pattern associated with a given ocular posture will continue after relaxation is attempted or after the innervation stimulus is removed. It was proposed that when a new instruction to reset the output is received by an oculomotor center, a new level of tonus control is established, and along with it a new degree of hysteresis. Accordingly, if successive hysteresis effects are in opposite directions, they will cancel each other, and, if in the same direction, will add algebraically. Thus, isotonic eye-movement exercises will be effective in producing erasure only to the extent to which they arise from the motor center originally exhibiting the hysteresis effect. By tilting the head back to its original upright posture, for purposes of measuring the apparent straight-ahead eye position, the output from the utricles was modulated by the changing shear component of gravito-inertial force. It follows, from the formulation above, that this change in output serves to clear the tonus control center and to reset the output of the utricles to a new level. In contrast, unless the subject valuntarily moves his eyes up and down, the upwardacting muscles will continue to exhibit an aftereffect. Accordingly, this should result in a reduction in hysteresis effects attributable to the DR, and, as a consequence, the aftereffect of Shebilske and Fogelgren can be interpreted as due largely to the residual tonus of the upward-acting muscles reflecting the compensatory innervation issued to balance against the DR when the head was tilted.

\section{REFERENCES}

CoHen, M. M. Elevator illusion: Influences of otolithic organ activity and neck proprioception. Perception \& Psychophysics, 1973, 14, 401-406.

EвеNholtz, S. M. Aftereffects of sustained vertical divergence: Induced vertical phoria and illusory target height. Perception, in press.

Ebenholtz. S. M.. \& Shebilske, W. L. Instructions and the $A$ and $\mathrm{E}$ effects in judgments of the vertical. American Journal of Psychology, 1973. 86. 601-612.

Esenholtz. S. M., \& Shebilske, W. The doll reflex: Ocular counterrolling with head-body tilt in the median plane. Vision Research, 1975, 15, 713-717.

MatthaEI. R. Nachbewegungen beim Menschen (Untersuchungen über das sog Kohnstammsche Phänomen). Pflügers Archiv für die gesumte Physiologie, 1924, 202, 587-600.

Scrubert, G., \& Brecher, G. A. Über optische Lokalisation und Augenstellung bei Vor-Rückwärtsneigung oder exzentrischer Rotation des Körpers. Zeitschrift für Sinnesphysiologie. 1935, 65, 1-26.

Shebilske. W. L.. \& Fogelgren, L. A. Eye-position aftereffects of backward head tilt manifested by illusory visual direction. Perception \& Psychophysics, 1977, 21, 77-82.

Szentagothai. J. Pathways and synaptic articulation patterns connecting vestibular receptors and oculomotor nuclei. In M. Bender (Ed.), The oculomotor system. New York: Harper \& Row, 1964.

TrINCKER, D. W. E. The transformation of mechanical stimulus into nervous excitation by the labyrinthine receptors. In Biological Receptor Mechanisms Symposium of the Society for Experimental Biology. Cambridge: Cambridge University Press. 1962. 